\title{
Feeding ecology and metabolism of the Antarctic cydippid ctenophore Callianira antarctica
}

\author{
Kerri M. Scolardi ${ }^{1,3, *}$, Kendra L. Daly ${ }^{1}$, Evgeny A. Pakhomov ${ }^{2,4}{ }^{,}$Joseph J. Torres $^{1}$ \\ ${ }^{1}$ College of Marine Science, University of South Florida, 140 Seventh Avenue South, St. Petersburg, Florida 33701, USA \\ ${ }^{2}$ Department of Zoology, Faculty of Science and Technology, University of Fort Hare, Private Bag X1314, Alice 5700, \\ South Africa
}

${ }^{3}$ Present address: Mote Marine Laboratory, 1600 Ken Thompson Parkway, Sarasota, Florida 34237, USA

${ }^{4}$ Present address: Department of Earth and Ocean Sciences, University of British Columbia, 6339 Stores Road, Vancouver, British Columbia V6T 1Z4, Canada

\begin{abstract}
The chemical composition, metabolism, and feeding ecology of the cydippid ctenophore Callianira antarctica (Chun 1897) were investigated during autumn and winter 2001 and 2002 in the vicinity of Marguerite Bay, an embayment on the western Antarctic Peninsula shelf. C. antarctica had relatively high carbon $(\mathrm{C}$ ) and nitrogen $(\mathrm{N})$ values (average: $8.4 \% \mathrm{C}$ and $1.8 \% \mathrm{~N}$ [\% dry weight, DW]), further suggesting that polar ctenophores are more C-rich than tropical species. Winter oxygen consumption and ammonium excretion rates ranged from 0.059 to $0.411 \mu \mathrm{O}_{2} \mathrm{mg}^{-1} \mathrm{DW} \mathrm{h}^{-1}$ and 0.043 to $2.22 \mathrm{nmol} \mathrm{N} \mathrm{mg}{ }^{-1} \mathrm{DW} \mathrm{h}^{-1}$, respectively, at $0^{\circ} \mathrm{C}$. Calanoid copepods, larval and juvenile Antarctic krill Euphausia superba and a mixture of prey were offered to ctenophores during feeding incubations. Ingestion rates based on preliminary feeding experiments were linearly related to prey densities, with rates ranging from 9 to 39 prey ind..$^{-1} \mathrm{~d}^{-1}$ and from 3.5 to 4.0 prey ind.$^{-1} \mathrm{~d}^{-1}$ for 1 larger and 1 smaller $C$. antarctica, respectively. Daily rations varied between 22 and $136 \%$ of body $\mathrm{C}$ for the larger ctenophore and 6 to $22 \%$ of body $\mathrm{C}$ for the smaller individual. Digestion time (median: $11.5 \mathrm{~h}$ ) was dependent on prey elemental content and prey number, and was independent of ctenophore size. Gut content analyses indicated that $C$. antarctica preyed predominantly on larval euphausiids and copepods. Diver observations, net collections, and diet analyses suggest that this species is an opportunistic predator that feeds both during the day and night, and appears to be well adapted to the prey patchiness found in Antarctic waters.
\end{abstract}

KEY WORDS: Antarctic zooplankton $\cdot$ Ctenophore $\cdot$ Krill $\cdot$ Copepod $\cdot$ Digestion time $\cdot$ Daily ration · Gut contents · Overwintering

Resale or republication not permitted without written consent of the publisher

\section{INTRODUCTION}

Recent scrutiny of the Antarctic pelagic ecosystem has uncovered a more complex system than the traditional trophic linkages (phytoplankton-krill-bird and mammal) originally thought to dominate (e.g. Hopkins 1985, Lancraft et al. 1989, Hopkins et al. 1993, Piatkowski et al. 1994, Voronina 1998). Many types of gelatinous zooplankton, including ctenophores, are now recognized as significant contributors to Antarctic marine ecosystem dynamics (Huntley et al. 1989, Pages \& Kurbjeweit 1994, Pages et al. 1996, Pages
1997). However, information on the ecology and physiology of Antarctic ctenophores is still lacking, thus leaving their role in the Southern Ocean uncertain.

Ctenophore densities in the Antarctic show considerable seasonal and interannual variability (Lancraft et al. 1989, 1991) and, at times, ctenophores may dominate total zooplankton wet biomass regionally (Pakhomov 1989). For example, ctenophore wet biomass has been observed to increase from 2 to more than $40 \%$ of the total zooplankton biomass in the upper $200 \mathrm{~m}$ of 3 oceanic stations in the Atlantic sector of the Southern Ocean between summer and autumn (Voronina et al. 1994). 
Furthermore, Callianira spp. made up 30 to $35 \%$ of the dry zooplankton biomass during early winter and spring of 2000 in the embayment of Deception Island, west of the Antarctic Peninsula (Kaufmann et al. 2003).

Ctenophores play an important role as predators in many ocean regions. Sporadic, dense blooms of ctenophores, driven by high fecundity and rapid growth rates (Reeve \& Walter 1976, 1978, Harbison et al. 1978), have a substantial impact on standing stocks of zooplankton prey when the two co-occur (e.g. Greene et al. 1986, Larson 1987a, Suthers \& Frank 1990, Swanberg \& Båmstedt 1991a,b, Mills 1995, Purcell 1997, Shiganovoa \& Bulgakova 2002). In the Antarctic, Daly \& Macaulay (1991) suggested that ctenophores may be important predators of overwintering larval Antarctic krill Euphausia superba, based on diver observations of high numbers of ctenophores feeding on larvae under sea ice during autumn and winter in the Scotia-Weddell seas. Hamner et al. (1989) and Hamner \& Hamner (2000) also reported diver observations during early autumn of Callianira antarctica under ice floes preying on larval krill west of the Antarctic Peninsula. These findings suggest that ctenophores may play a larger role in the Antarctic ecosystem than previously believed.

Assessing the ecological role of a species requires knowledge of its energy utilization and diet; but as stated earlier, there is little information on physiological rates or food web interactions for any Antarctic ctenophores. As part of the Southern Ocean Global Ocean Ecosystem Dynamics (GLOBEC) program, we investigated the ecology of the tentaculate ctenophore Callianira antarctica in the vicinity of Marguerite Bay, on the western Antarctic Peninsula shelf, during austral autumn and winter. In this paper, we report the first data on elemental composition, metabolic rates, feeding behavior, digestion rates, and diet of $C$. antarctica.

\section{MATERIALS AND METHODS}

Study area. Data were collected as part of the German and US Southern Ocean GLOBEC programs in the vicinity of Marguerite Bay, west of the Antarctic Peninsula (Fig. 1). The observations reported here were obtained aboard the RV 'Polarstern' (25 April to 2 May 2001), the RV 'Lawrence M. Gould' (7 April to 20 May 2002), and the RVIB 'Nathaniel B. Palmer' (24 July to 31 August 2001 and 31 July to 18 September 2002). Seawater temperature and salinity ranged from -1.8 to $1.8^{\circ} \mathrm{C}$ and 33.0 to 34.75 , respectively, within the study area (Klinck et al. 2004).

Sampling. Preliminary ingestion experiments were measured during in vitro incubations on board the RV

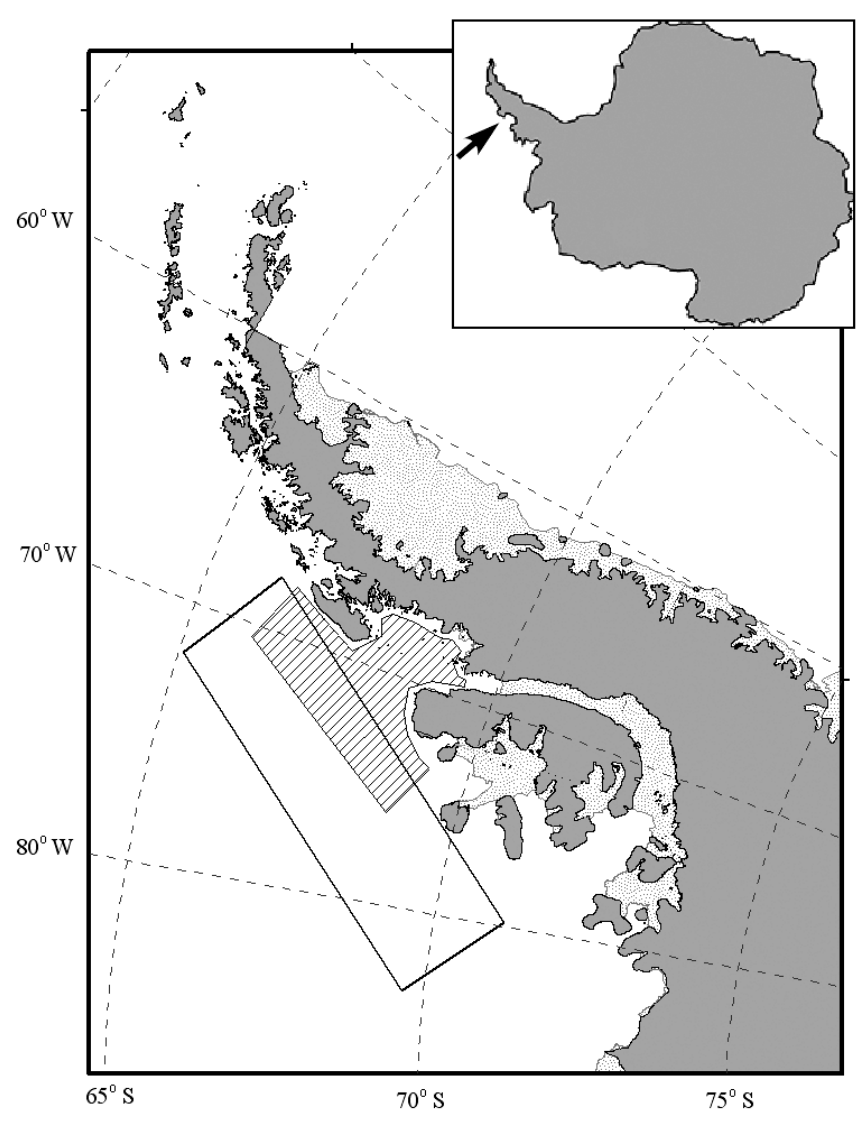

Fig. 1. The study area near Marguerite Bay, west of the Antarctic Peninsula. The large box denotes the location of the RV 'Polarstern' cruise (25 April to 2 May 2001); hatched area denotes the location of RV 'Lawrence M. Gould' (7 April to 20 May 2002) and RVIB 'Nathaniel B. Palmer' cruises (24 July to 31 August 2001 and 31 July to 18 September 2002)

'Polarstern' during austral autumn 2001. An Apstein net $(0.3 \mathrm{~m}$ diameter, $150 \mu \mathrm{m}$ mesh with non-filtering cod end) was used to collect ctenophores and prey from the upper $25 \mathrm{~m}$ of the water column. Prey were also collected for experiments with a Bongo net from between 0 and $300 \mathrm{~m}$.

All other observations of ctenophores and live experiments were done on board the 'Gould' and 'Palmer'. During winter 2001 and autumn 2002, ctenophores and prey were primarily collected using a $1.5 \mathrm{~m}^{2}$ Tucker trawl, with a $6.4 \mathrm{~mm}$ mesh net attached to a $0.5 \mathrm{~m}$ $(707 \mu \mathrm{m})$ plankton net, equipped with a non-filtering cod end. The Tucker trawl was towed obliquely within the upper $200 \mathrm{~m}$ of the water column. Ctenophores were also occasionally removed from $1 \mathrm{~m}^{2}$ and $10 \mathrm{~m}^{2}$ MOCNESS (Multiple Opening/Closing Net and Environmental Sensing System) nets, with $333 \mu \mathrm{m}$ and $3 \mathrm{~mm}$ meshes, respectively. These nets were towed at discrete depth intervals throughout the water column. Tucker and MOCNESS tow speeds were 1.5 to 
2.5 knots. Due to heavy ice conditions in winter 2002, ctenophores and prey were mainly collected using a $1 \mathrm{~m}$ diameter Reeve net (333 $\mu \mathrm{m}$ mesh) with a 201 nonfiltering cod end. The Reeve net was deployed parallel to the water surface between 10 and $15 \mathrm{~m}$ depth off the stern, while the propellers were run at 15 to $25 \%$ pitch to keep water circulating into the net, but with little forward ship movement or ice sweep-down into the net. This approach retrieved animals in exceptionally good condition. Ctenophores were immediately separated from the catch once on board and gently placed in a bucket of $0.1 \mu \mathrm{m}$ filtered seawater at sea surface temperature $\left(-1.8\right.$ to $\left.0^{\circ} \mathrm{C}\right)$.

Ctenophores were also hand-collected in individual jars by SCUBA divers working in the upper $10 \mathrm{~m}$ of the water column under sea ice during winter 2001 and 2002. At the surface, jars were placed in buckets of seawater to prevent freezing and injury to ctenophores. SCUBA dives were generally conducted during mid-afternoon hours.

Chemical composition. Ctenophores collected in good condition during autumn and winter 2002 were used for chemical analyses. Total length (distance from the mouth to the tip of the aboral keels) was measured to the nearest $\mathrm{mm}$ on individuals submerged in filtered seawater in a deep glass dish. After draining seawater from the dish, individuals were gently blotted with a Kimwipe to remove excess water, being careful not to remove tentacular material, and frozen at $-80^{\circ} \mathrm{C}$. After returning to the laboratory, individuals were placed in preweighed, combusted aluminum boats, weighed to the nearest $0.1 \mathrm{mg}$, and dried at $60^{\circ} \mathrm{C}$ to a constant dry weight (DW). Water content was determined by the difference between wet and dry weight. Dried ctenophores were thoroughly homogenized, subsampled, and analyzed for carbon (C) and nitrogen (N) content by the Marine Science Institute Analytical Laboratory, University of California Santa Barbara (UCSB).

Metabolic rates. Active and undamaged ctenophores were collected for respiration and excretion experiments either by divers or by the Reeve net during winter 2002. Oxygen $\left(\mathrm{O}_{2}\right)$ consumption rates were measured on individuals using sealed vessel respirometry (Ikeda et al. 2000). $\mathrm{O}_{2}$ concentrations were monitored continuously using a 30 channel oxygen electrode system as the animals reduced the oxygen in sealed, water-jacketed chambers to intermediate ( $30 \mathrm{mmHg}$ ) partial pressures. Control chambers were also monitored. Electrodes were calibrated using air and nitrogen saturated seawater at experimental temperature. Ctenophores were kept in the dark and water temperature was maintained at $0.5^{\circ} \mathrm{C}\left( \pm 0.1^{\circ} \mathrm{C}\right)$ using a refrigerated water-bath.

At the end of each experiment, ctenophores were frozen and stored at $-80^{\circ} \mathrm{C}$ for later processing and analysis of $\mathrm{C}$ and $\mathrm{N}$ as described above. $\mathrm{O}_{2}$ consumption rates were calculated over 30 min intervals following the initial excitatory period, which was usually 1 to $2 \mathrm{~h}$, and above the critical oxygen partial pressure (30 mm Hg) for ctenophores. The values for each interval were then summed and averaged over the entire time period to give a mean respiration rate for each individual. Water from the respiration chambers was subsampled and either analyzed immediately for ammonium excretion or frozen at $-20^{\circ} \mathrm{C}$ and analyzed within a week, following methods described by Gordon et al. (1993).

Ingestion rates and daily ration. During autumn 2001, 6 consecutive ingestion experiments were conducted using a single 'larger' (total length $35 \mathrm{~mm}$, $3.3 \mathrm{mg} \mathrm{C}$ ) ctenophore and 3 were performed using a single 'smaller' (25 mm, $2.4 \mathrm{mg} \mathrm{C}$ ) individual. Prior to incubation, the larger and smaller ctenophores were starved for 6 and $2 \mathrm{~h}$, respectively. After each experiment, they were transferred immediately to the next incubation container. The larger ctenophore was incubated in an 81 container (ctenophore:incubation volume ratio of $\sim 1: 533$ ) for the first 2 experiments and in a 251 container (ratio of $\sim 1: 1670$ ) thereafter. The smaller ctenophore was incubated in a 51 container (ratio of 1:700). Known numbers of prey were introduced into experimental containers filled with $0.2 \mu \mathrm{m}$ filtered seawater. There were no injured or dead prey in containers after experiments; all missing prey were attributed to ctenophore predation. Experimental temperature was maintained between 0 and $-1^{\circ} \mathrm{C}$, close to ambient surface water temperatures. All experiments lasted $24 \mathrm{~h}$ and were conducted under $\operatorname{dim}(<5 \%$ of ambient daylight) light conditions.

After incubation, all remaining prey were collected on $200 \mu \mathrm{m}$ mesh, counted, blotted with a Kimwipe, and frozen at $-70^{\circ} \mathrm{C}$. At the completion of feeding experiments, ctenophores were also frozen at $-70^{\circ} \mathrm{C}$. Prey were analyzed for $\mathrm{C}$ and $\mathrm{N}$ in 6 to 12 replicates after oven-drying at $60^{\circ} \mathrm{C}$ for $24 \mathrm{~h}$. Ctenophores were placed in pre-weighed, combusted aluminum foil containers, oven-dried at $60^{\circ} \mathrm{C}$ for $36 \mathrm{~h}$, homogenized, and subsampled for analysis. $\mathrm{C}$ and $\mathrm{N}$ contents of ctenophores and prey were determined with a Carlo Erba 1500 CHN-analyzer.

Clearance rates were calculated using the Frost (1972) equation, assuming an exponential decrease of prey during incubations:

$$
F=\left\{\left[\ln \left(n_{\mathrm{i}}\right)-\ln \left(n_{\mathrm{f}}\right)\right] \times V\right\} / t
$$

where $F$ is clearance rate per ctenophore $\left(\mathrm{ld}^{-1}\right), n_{\mathrm{i}}$ is the initial density of prey (ind. $\mathrm{l}^{-1}$ ), $n_{\mathrm{f}}$ is the density of prey at the end of the feeding period (ind. $1^{-1}$ ), $V$ is the volume of the experimental container (1), and $t$ is the duration of the experiment (in days). 
Estimation of digestion time. Digestion rate experiments were conducted during winter 2002. Single active and undamaged ctenophores were placed in $960 \mathrm{ml}$ polypropylene jars containing $0.1 \mu \mathrm{m}$ filtered seawater, and incubated in the dark in a large flowthrough aquarium to maintain in situ sea surface temperature $\left(-1.3\right.$ to $\left.-1.8^{\circ} \mathrm{C}\right)$. After an initial $24 \mathrm{~h}$ starvation, individual ctenophores were placed into $500 \mathrm{ml}$ polypropylene jars containing prey in $0.1 \mu \mathrm{m}$ filtered seawater and returned to the flow-through aquarium. Prey offered in experiments were the same species and sizes that were observed in ctenophore gut contents from in situ feeding, including larval and juvenile euphausiids Euphausia superba and Thysanoessa macrura, and the calanoid copepods Calanoides acutus, Calanus propinquus, and Metridia gerlachii. Experimental containers were checked hourly until the ctenophore ingested prey $\left(t_{0}\right)$. After ingestion, the ctenophore was placed in a 500 or $960 \mathrm{ml}$ container (depending on its size) with filtered seawater, and held in the flow-through aquarium. Digestion was observed hourly for the first 2 to $3 \mathrm{~h}$ of the experiment. Thereafter, the progress of digestion determined the frequency (every 1 to $2 \mathrm{~h}$ ) of subsequent observations in order to minimize disturbance. During each inspection, ctenophores were submerged in a deep glass dish, briefly viewed under a dissecting microscope with dim light, and then placed into a fresh container of filtered seawater. The old container water was filtered through a $20 \mu \mathrm{m}$ mesh sieve, back-washed into a small dish, and examined under a dissecting microscope. Experiments were continued until there were no recognizable remains of prey in the stomodeum and infundibulum, and no further material was egested. Of the 7 animals 6 were used in multiple experiments, each one preceded by $24 \mathrm{~h}$ of starvation. Animals that did not ingest prey within $48 \mathrm{~h}$ of the termination of the previous experiment were measured and frozen at $-80^{\circ} \mathrm{C}$.

Digestion time was defined as the time elapsed between ingestion of prey and clearing of the gastrovascular cavity, estimated to the nearest hour. In order to express digestion time in terms of ingested prey $\mathrm{C}, \mathrm{N}$, or DW, prey species of the same stage and/or size as those used in the digestion experiments were sorted, measured for length, rinsed briefly with cold distilled water to remove salts, blotted dry, and frozen at $-80^{\circ} \mathrm{C}$. In the laboratory, individual euphausiids or grouped copepods were placed onto preweighed, combusted filters, and wet weights (WW) were determined to the nearest $0.1 \mathrm{mg}$. Specimens were then dried at $60^{\circ} \mathrm{C}$ to a constant weight and analyzed for $\mathrm{C}$ and $\mathrm{N}$.

Gut contents. Ctenophores collected during winter 2001 and autumn and winter 2002 were analyzed for gut contents within 30 min after retrieval, with the exception of a few high-density tows, where analysis took up to $2 \mathrm{~h}$. Ctenophores collected by divers were visually inspected on site and analyzed as soon as the dive was completed ( 1 to $2 \mathrm{~h}$ ). Individuals were measured for total length, and gut contents were examined either by dissection of the gastrovascular cavity or by suction-removal of gut contents using a pipette inserted into the gastrovascular cavity. Prey items were identified to the lowest possible taxonomic category. In order to reduce bias due to possible netfeeding, prey that were newly ingested and had not reached the proximate half of the stomach were eliminated from the final count.

Statistical analysis. Much of the data reported here were not normally distributed, and therefore, the median and range are used to describe the central trend of those data. For percentage and rate measurements, the geometric mean (Laws \& Archie 1981, Zar 1990) is reported if the value was different from the calculated arithmetic mean. Correlation and regression analyses were calculated at the $5 \%$ significance level.

\section{RESULTS}

\section{Chemical composition}

A total of 32 Callianira antarctica, 8 from autumn and 24 from winter 2002, were measured for total length, WW, DW, and $\mathrm{C}$ and $\mathrm{N}$ content (Table 1). The relationship between length $(L, \mathrm{~mm})$ and dry weight (DW, mg) for autumn and winter was DW $=0.58 L^{1.59}\left(\mathrm{r}^{2}=0.92\right)$ and DW $=0.018 L^{2.49}\left(\mathrm{r}^{2}=0.96\right)$, respectively. None of the individuals had prey in their guts, although $44 \%$ did have lipids. There was no significant difference ( $p>0.5$ ) in $\mathrm{C}$ and $\mathrm{N}$ content between ctenophores with or without lipids in their guts. Although winter $\mathrm{C}$ and $\mathrm{N}$ (\% DW) values were more variable than autumn values, there was no significant difference (MannWhitney $U$-test, \% C: $\mathrm{p}=0.54, \% \mathrm{~N}: \mathrm{p}=0.93$ ) between seasons. Therefore, averages of the combined data are shown as well (Table 1). The geometric mean C:N ratios were also similar between seasons (geometric mean [range] for autumn: 4.48 [4.0 to 5.17]; winter: 4.65 [3.64 to 9.67]). The relationship between ctenophore DW and body $\mathrm{C}$ and $\mathrm{N}$ for autumn and winter are shown in Fig. 2.

\section{Metabolic rates}

During winter 2002, oxygen consumption and ammonium excretion rates (Table 2) were measured for 10 ctenophores ranging in total length from 8.5 to $85.0 \mathrm{~mm}$, with a median length of $31.0 \mathrm{~mm}$. Oxygen 
Table 1. Callianira antarctica. Total length, dry weight (DW), water content as percent of wet weight (WW), and body carbon and nitrogen as percent of DW are shown for autumn and winter 2002, separately, and for combined data. Median values are given for length and DW, and geometric mean (GeoMean) values for water and elemental composition. Ranges are provided for all measurements. n: number of individuals analyzed

\begin{tabular}{|c|c|c|c|c|c|c|c|c|c|c|c|}
\hline \multirow[t]{2}{*}{ Season } & \multicolumn{2}{|c|}{$\begin{array}{l}\text { Total length } \\
\text { (mm) }\end{array}$} & \multicolumn{2}{|c|}{$\begin{array}{c}\text { Dry weight } \\
\text { (mg) }\end{array}$} & \multicolumn{2}{|c|}{$\begin{array}{l}\text { Water } \\
(\% \text { WW })\end{array}$} & \multicolumn{2}{|c|}{$\begin{array}{l}\text { Carbon } \\
(\% \text { DW) }\end{array}$} & \multicolumn{2}{|c|}{$\begin{array}{c}\text { Nitrogen } \\
(\% \text { DW) }\end{array}$} & \multirow[t]{2}{*}{$\mathrm{n}$} \\
\hline & Median & Range & Median & Range & GeoMean & Range & GeoMean & Range & GeoMean & Range & \\
\hline Autumn & 46.5 & $35.0-83.6$ & 276 & $150-758$ & 96.1 & $95.7-97.9$ & 8.60 & $7.00-12.0$ & 1.92 & $1.55-2.38$ & 8 \\
\hline Winter & 25.5 & $8.5-98.0$ & 76.6 & $2.8-1366$ & 95.5 & $94.2-97.0$ & 8.35 & $1.41-24.9$ & 1.80 & $0.30-4.43$ & 24 \\
\hline Combined & 34.5 & $8.5-98.0$ & 132 & $2.8-1366$ & 95.7 & $94.2-97.9$ & 8.41 & $1.41-24.9$ & 1.83 & $0.30-4.43$ & 32 \\
\hline
\end{tabular}

consumption $\left(\mu \mathrm{l} \mathrm{O}_{2}\right.$ ind..$\left.^{-1} \mathrm{~h}^{-1}\right)$ increased with increasing ctenophore DW (mg) according to the equation: $y=$ $0.237 \mathrm{DW}^{0.919}\left(\mathrm{r}^{2}=0.91\right.$; Fig. 3). Carbon-specific oxygen consumption showed a slightly lower slope, $y=$ $3.762 x^{0.707}\left(x, \mathrm{mg} \mathrm{C}_{;} \mathrm{r}^{2}=0.95\right)$, due to the higher carbon content in larger individuals. Nitrogen excretion rate ( $\mu \mathrm{mol} \mathrm{N}$ ind.$^{-1} \mathrm{~h}^{-1}$ ) scaled less steeply with ctenophore DW (mg): $y=0.006 \mathrm{DW}^{0.487}\left(\mathrm{r}^{2}=0.62 ;\right.$ Fig. 3). Since the slopes of all curves were less than 1, weight-specific oxygen consumption and excretion rate both declined with increasing weight (Table 2, Fig. 3), as is typical of virtually all species studied to date (Withers 1992). The lower slope of the excretion vs. weight curve resulted from a more profound drop in weight-specific excretion rate with increasing weight than was observed in the oxygen consumption data. Thus, DW-specific oxygen consumption rates calculated for individual Callianira antarctica ranged from 0.059 to $0.411 \mu \mathrm{O}_{2}$ $\mathrm{mg}^{-1} \mathrm{DW} \mathrm{h}^{-1}$ for individuals weighing 1049 and $174.2 \mathrm{mg}$ DW, respectively (Table 2); DW-specific nitrogen excretion rates ranged from 0.043 to $2.221 \mathrm{nmol} \mathrm{N} \mathrm{mg}^{-1} \mathrm{DW} \mathrm{h}^{-1}$ for individuals weighing 1049 and $2.8 \mathrm{mg}$ DW, respectively.

The ratio of oxygen uptake to nitrogen-excretion rate (atomic O:N ratio) varied from 5.6 to 122.4, with no relationship to ctenophore size (Table 2). Plotting $\mu$ mol $\mathrm{O}$ ind..$^{-1} \mathrm{~h}^{-1}$ vs. $\mu \mathrm{mol} \mathrm{N}$ ind..$^{-1} \mathrm{~h}^{-1}$, with the $y$ intercept constrained to pass through 0 , yields a slope of 30.3, which is a good global approximation for the winter O:N ratio (geometric mean 25.5, arithmetic mean 38.3). These results suggest a metabolism based primarily on lipid, with a few low values suggesting recent prey capture and protein digestion.

Since ctenophores were apparently metabolizing both protein and lipids (cf. Kremer 1977), the range of minimum daily carbon requirements was estimated by converting the mean oxygen consumption rate per individual to carbon utilization using Gnaiger's (1983) respiratory quotient (RQ) values of 0.97 for protein and 0.72 for lipid catabolism. Callianira antarctica's daily carbon requirement during winter ranged from 3.60 to $190 \mu \mathrm{g} \mathrm{C}$ (1.2 to $8.9 \%$ of total body carbon) for smaller ctenophores (8.5 to $28 \mathrm{~mm}$ total length [TL]), and from $151 \mu \mathrm{g}$ to $1.13 \mathrm{mg} \mathrm{C}$ ( 0.44 to $3.6 \%$ of total body carbon) for larger ctenophores (34 to $85 \mathrm{~mm} \mathrm{TL}$ ).

\section{Feeding behavior}

During winter 2001 and 2002, SCUBA divers observed high numbers of Callianira sp. (>1 ctenophore $\mathrm{m}^{-3}$ ) just under the pack ice, concurrent with larval krill aggregations. Ctenophores were
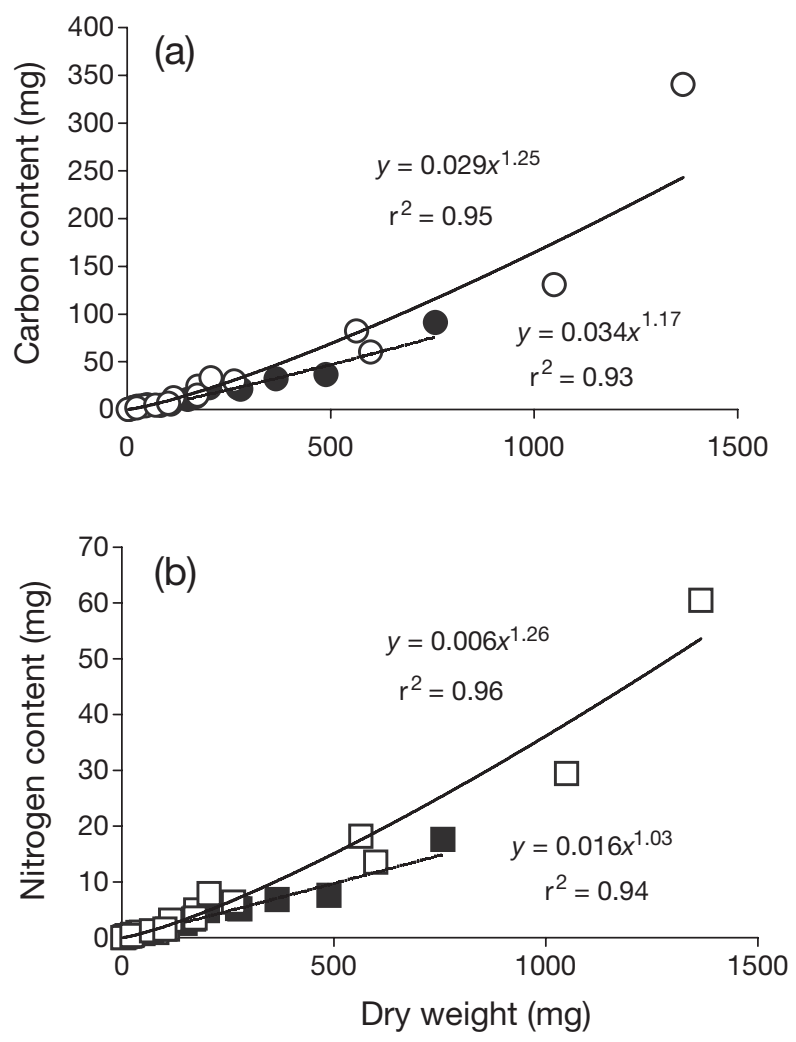

Fig. 2. Callianira antarctica. The seasonal relationships between (a) dry weight and total carbon and (b) dry weight and total nitrogen for (filled symbols) autumn and (open symbols) winter 2002 
Table 2. Callianira antarctica. DW, carbon content, respiration, and excretion for individual ctenophores. Note the general increase in carbon (\% DW) with increasing weight. The global O:N value reported in the text was derived from the slope of a linear plot of respiration vs. excretion, both expressed in $\mu \mathrm{mol}$ ind.$^{-1} \mathrm{~h}^{-1}$

\begin{tabular}{|ccccccc|}
\hline Dry weight & Carbon & \multicolumn{2}{c}{$\begin{array}{c}\text { Respiration } \\
\left(\mu \mathrm{l} \mathrm{h}^{-1}\right)\end{array}$} & $\begin{array}{c}\text { Excretion } \\
\left(\mathrm{nmol} \mathrm{N} \mathrm{h}^{-1}\right)\end{array}$ & O:N \\
& $(\mathrm{mg})$ & $(\% \mathrm{DW})$ & $\mathrm{mg}^{-1} \mathrm{DW}$ & $\mathrm{mg}^{-1} \mathrm{C}$ & $\mathrm{mg}^{-1} \mathrm{DW}$ & \\
\hline & 2.8 & 1.9 & 0.139 & 7.147 & 2.221 & 5.6 \\
& 24.6 & 5.9 & 0.181 & 3.071 & 0.756 & 21.4 \\
& 38.7 & 9.1 & 0.277 & 3.039 & 1.067 & 23.2 \\
& 70.5 & 6.4 & 0.158 & 2.483 & 1.135 & 12.4 \\
& 107.5 & 5.2 & 0.151 & 2.905 & 0.542 & 24.9 \\
& 115.2 & 10.5 & 0.132 & 1.265 & 1.084 & 10.9 \\
& 173.0 & 8.5 & 0.167 & 1.957 & 0.430 & 34.6 \\
& 174.2 & 13.8 & 0.411 & 2.972 & 0.376 & 97.5 \\
Mean & 564.0 & 14.6 & 0.161 & 1.103 & 0.484 & 29.6 \\
SD & 1049 & 12.5 & 0.059 & 0.471 & 0.043 & 122.4 \\
& 232.0 & 8.8 & 0.184 & 2.641 & 0.814 & 38.3 \\
& 328.8 & 4.1 & 0.096 & 1.834 & 0.609 & 39.2 \\
\hline
\end{tabular}

mass (Fig. 4). The amount of consumed prey increased with initial prey density without reaching a saturation point during the experiments. This, however, was not the case for the smaller $C$. antarctica, perhaps due to a non-optimal size range of prey items, saturated feeding owing to high prey densities, or both. Daily rations ranged from 22 to $136 \%$ of body $\mathrm{C}$ for the larger ctenophore and from 6 to $22 \%$ for the smaller ctenophore and were positively correlated with initial food concentration (Table 3).

\section{Digestion time}

passively drifting with their mouth oriented upward and tentacles extended outward to approximately 10 times their body length or more, characteristic of an ambush entangling predator (Greene 1985). Ctenophores imaged under ice during late night hours by a remotely operated vehicle (ROV) showed similar behavior.

Callianira antarctica feeding behavior was also observed during digestion experiments. Individuals set out their tentacles while swimming in a circular pattern. After prey became entangled in a tentacle, the ctenophore retracted the tentacle, drawing the prey close to its body, and then rotated several times in the tentacular plane, effectively landing the prey held by the tentacle into its mouth. The prey, along with the portion of tentacle surrounding it, was moved quickly (typically <30 min) from the mouth down into the stomodeum (pharynx). C. antarctica was able to successfully capture and ingest Euphausia superba furcilia and juveniles up to $24 \mathrm{~mm}$ in length, the size range observed swarming near the undersurface of sea ice in winter.

\section{Clearance rates, ingestion rates, and daily rations}

Clearance rates of prey assemblages ranged from 3.2 to $17.9 \mathrm{l}$ ind..$^{-1} \mathrm{~d}^{-1}$ for the larger ctenophore and from 0.4 to $1.1 \mathrm{l}$ ind.$^{-1} \mathrm{~d}^{-1}$ for the smaller ctenophore (Table 3 ). Ingestion rates of the larger Callianira antarctica were linearly related to prey densities, in terms of numbers, carbon, and nitrogen mass (Table 3), as illustrated by carbon
A single digestion experiment was carried out during autumn 2001 at $0.5^{\circ} \mathrm{C}$ using a small ctenophore (13 mm), which had a freshly consumed krill furcilia 3 in its stomodeum. Total digestion time was $9 \mathrm{~h}$. During winter 2002, 21 digestion time experiments were performed with ctenophores ranging in size from 20 to $55 \mathrm{~mm}$ TL. Nearly half of the experiments (48\%) involved digestion of 1 prey item, and $14 \%$ had 2 prey. The largest meal digested was 6 prey $(\mathrm{n}=1)$. Winter digestion times ranged from 5 to $46 \mathrm{~h}$, with $86 \%$ of the experiments having digestion completed within 8 to $20 \mathrm{~h}$ at $-1.8^{\circ} \mathrm{C}$. The median digestion time was $11.5 \mathrm{~h}$. In order to compare digestion rates among experiments involving multiple prey, digestion times were normalized by prey DW, C, or N (Table 4).

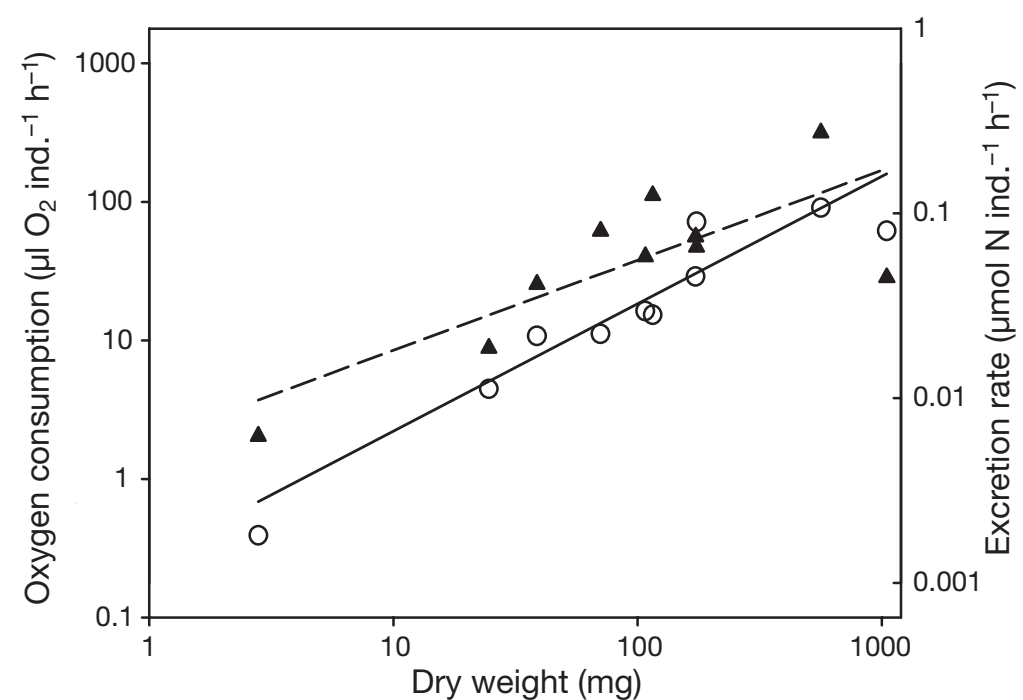

Fig. 3. Callianira antarctica. Relationship between DW and (O) oxygen consumption or $(\boldsymbol{\Delta})$ ammonium excretion. Temperature $=0.5^{\circ} \mathrm{C}$ 


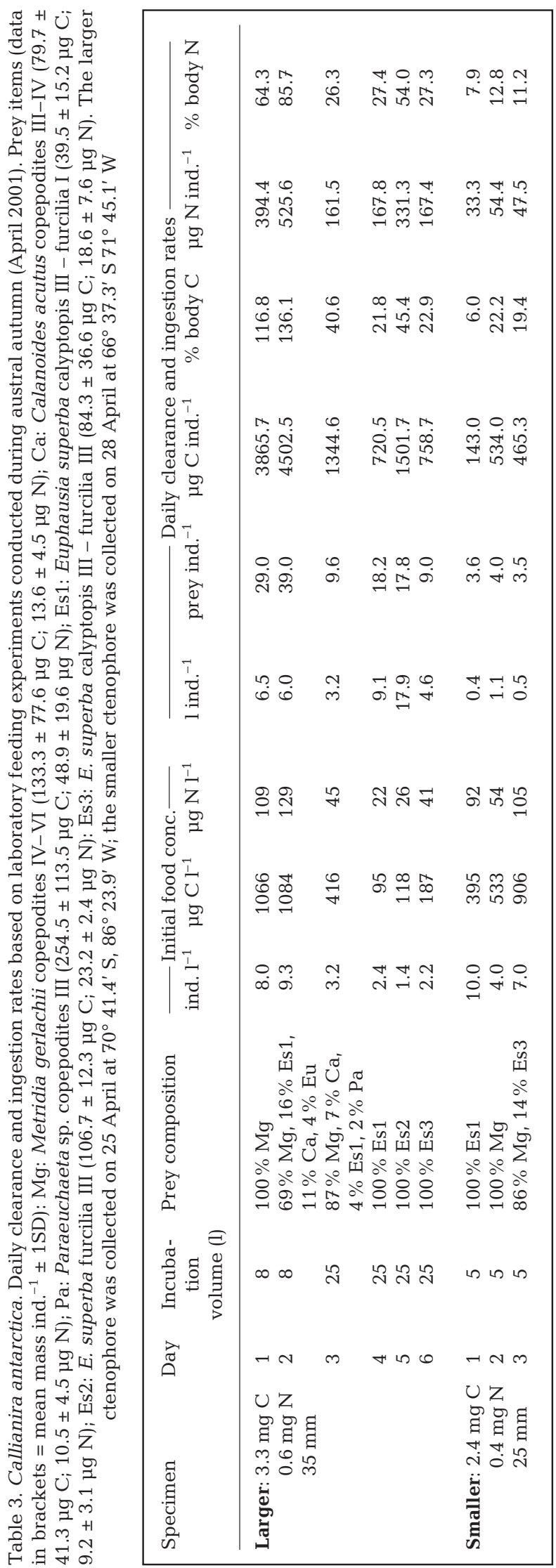

Both simple and multiple linear regression analyses indicated that ctenophore length was not a significant source of variation in digestion time, even allowing for the maximum digestion time as an outlier (Fig. 5a). In contrast, prey carbon $\left(\mathrm{r}^{2}=0.91\right.$; Fig. 5b), nitrogen $\left(\mathrm{r}^{2}=\right.$ $0.85)$ and dry weight $\left(\mathrm{r}^{2}=0.88\right)$ were all important determinants of digestion time. The maximum digestion time was included in these analyses as it was the result of a highly carbon-rich meal from the ingestion of 2 juvenile Thysanoessa macrura (see below), and is likely representative of prey ingested in situ. Given that elemental content varies among prey species, prey type was a secondary factor influencing digestion times, i.e. species rich in carbon (lipids) and nitrogen, such as the euphausiid T. macrura and the copepod Calanus propinquus, usually took longer to digest (Table 4, Fig. 6). For example, a single T. macrura took 1.4 times longer to digest than a larger Euphausia superba with approximately 2-fold lower carbon content (T. macrura: $7.37 \mathrm{mg} \mathrm{C}$; E. superba: $4.26 \mathrm{mg} \mathrm{C}$ ).

Prey number did not have a significant linear relation with digestion when all data were considered ( $p>0.05$, Fig. 6). However, some species of similar size and lipid content showed a strong relationship between prey number $\left(n_{\mathrm{p}}\right)$ and digestion time $(D T)$ (e.g. Calanus propinquus: $D T=2.39 n_{\mathrm{p}}+7.66, \mathrm{r}^{2}=$ 0.90). Furthermore, the increase in digestion time with prey number did not necessarily correlate with increased carbon intake. For example, multiple Euphausia superba furcilia 6 (total $<2.0 \mathrm{mg} \mathrm{C}$ ) took almost $30 \mathrm{~min}$ longer to digest than a single E. superba juvenile ( $4 \mathrm{mg} \mathrm{C})$. In this instance, the increased size of the food bolus or refractory body components probably slowed digestion. Ultimately, a stepwise regression analysis indicated that the best multivariate model was obtained using both prey carbon $(\mathrm{C})$ and prey number $\left(n_{\mathrm{p}}\right)$, and excluding the

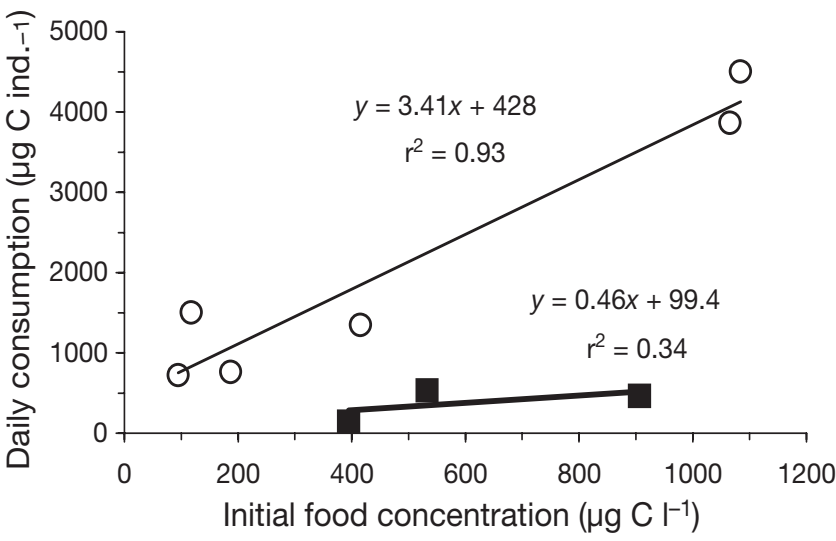

Fig. 4. Callianira antarctica. Individual daily consumption rates, in terms of prey carbon, for (O) 1 larger and (ロ) 1 smaller ctenophore at various prey densities 
Table 4. DW, body carbon $(\mathrm{C})$ and body nitrogen $(\mathrm{N})$ of zooplankton prey types used in winter digestion experiments. Euphausia superba values were calculated from length $(L)$ vs. DW and DW vs. carbon or nitrogen content regressions (see footnotes a,b below). Median values of measured dry weights and elemental composition are shown for all other species. F: furcilia stage; Juv: juvenile; Fe: female; Ma: male; n: number of individuals analyzed

\begin{tabular}{|c|c|c|c|c|c|c|c|c|}
\hline Prey & Stage/Sex & Size $(\mathrm{mm})$ & DW ( $\mu g)$ & $C(\mu g)$ & $\mathrm{N}(\mu g)$ & $\mathrm{C} \% \mathrm{DW}$ & $\mathrm{C}: \mathrm{N}$ & $\mathrm{n}$ \\
\hline Euphausia superba & $\mathrm{F} 4$ & $6-8$ & $514 \pm 27.4$ & $160^{\mathrm{a}}$ & $43.6^{\mathrm{a}}$ & 31.1 & 3.67 & 8 \\
\hline Euphausia superba & F5 & $7-9$ & $809 \pm 41.6$ & $221^{\mathrm{a}}$ & $60.1^{\mathrm{a}}$ & 27.3 & 3.68 & 10 \\
\hline Euphausia superba & F6 & $8-11$ & $1080 \pm 51.0$ & $277^{a}$ & $75.2^{\mathrm{a}}$ & 25.6 & 3.68 & 26 \\
\hline Euphausia superba & Juv & 20 & $10309^{b}$ & $4264^{\mathrm{b}}$ & $879^{\mathrm{b}}$ & 41.4 & 4.85 & 33 \\
\hline Thysanoessa macrura & Juv & $11-15$ & 6478 & 3279 & 565 & 50.6 & 5.80 & 5 \\
\hline Thysanoessa macrura & Juv & $15-20$ & 14530 & 7369 & 1039 & 50.7 & 7.09 & 4 \\
\hline Metridia gerlachi & $\mathrm{Fe}$ & $3-5$ & 313 & 103 & 20.1 & 32.9 & 5.12 & 6 \\
\hline Calanus propinquus & $\mathrm{Fe} \& \mathrm{Ma}$ & $4-6$ & 1173 & 571 & 88.6 & 48.7 & 6.44 & 19 \\
\hline
\end{tabular}

maximum digestion time $(46 \mathrm{~h}): D T=7.77+0.699 \mathrm{C}$ $+0.344 n_{\mathrm{p}}\left(\mathrm{r}^{2}=0.73, \mathrm{p}=0.00001\right)$.

Five stages were used to quantify the digestion process (Fig. 7) and to compare it with observations of in situ gut contents. Three digestion experiments were omitted from this analysis because small, lingering portions of prey tissue or an excessive amount of food ingested resulted in exceptionally long digestion
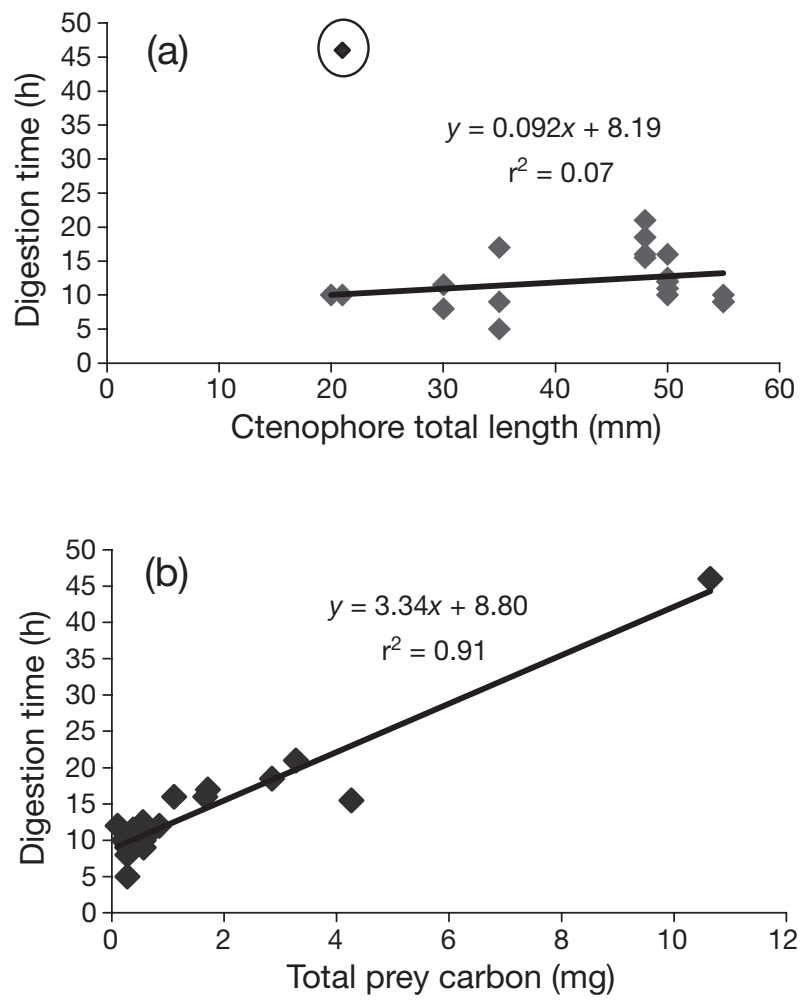

Fig. 5. Callianira antarctica. The relationship between total digestion time and (a) ctenophore body size and (b) prey carbon content $(\mathrm{n}=21)$. The maximum digestion time (encircled) was omitted from the regression in (a) times. Callianira antarctica typically digested soft tissue first and egested exoskeletal remains through its mouth last, with the exception of a few occasions when soft tissue remained after the exoskeleton was egested. Digestion Stage II consistently occurred within $5 \mathrm{~h}$ after ingestion of prey and Stage III within 9 h. Duration of Stages IV and V, however, was much more variable, ranging from 3 to 18 and 5 to 21 h, respectively, depending on prey type and/or carbon content.

\section{Lipid storage}

Callianira antarctica does not have distinct oil sacs like Mertensia ovum, but instead accumulates lipids from digested prey in the stomodeum (Larson \& Har-

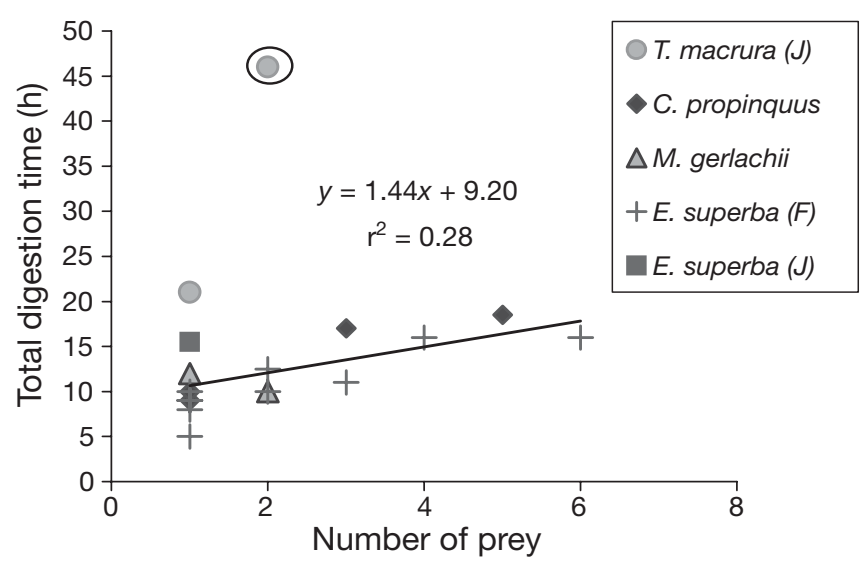

Fig. 6. Callianira antarctica. Relationship between number and type of prey ingested vs. total digestion time $(n=19)$. Prey types are represented by the symbols indicated in the figure legend. Two experiments in which there was more than 1 type of prey ingested were omitted. The maximum digestion time (encircled) was omitted from the regression. T. macrura: Thysanoessa macrura; C. propinquus: Calanus propinquus; M. gerlachii: Metridia gerlachii; E. superba: Euphausia superba; J: juvenile; F: furcilia 

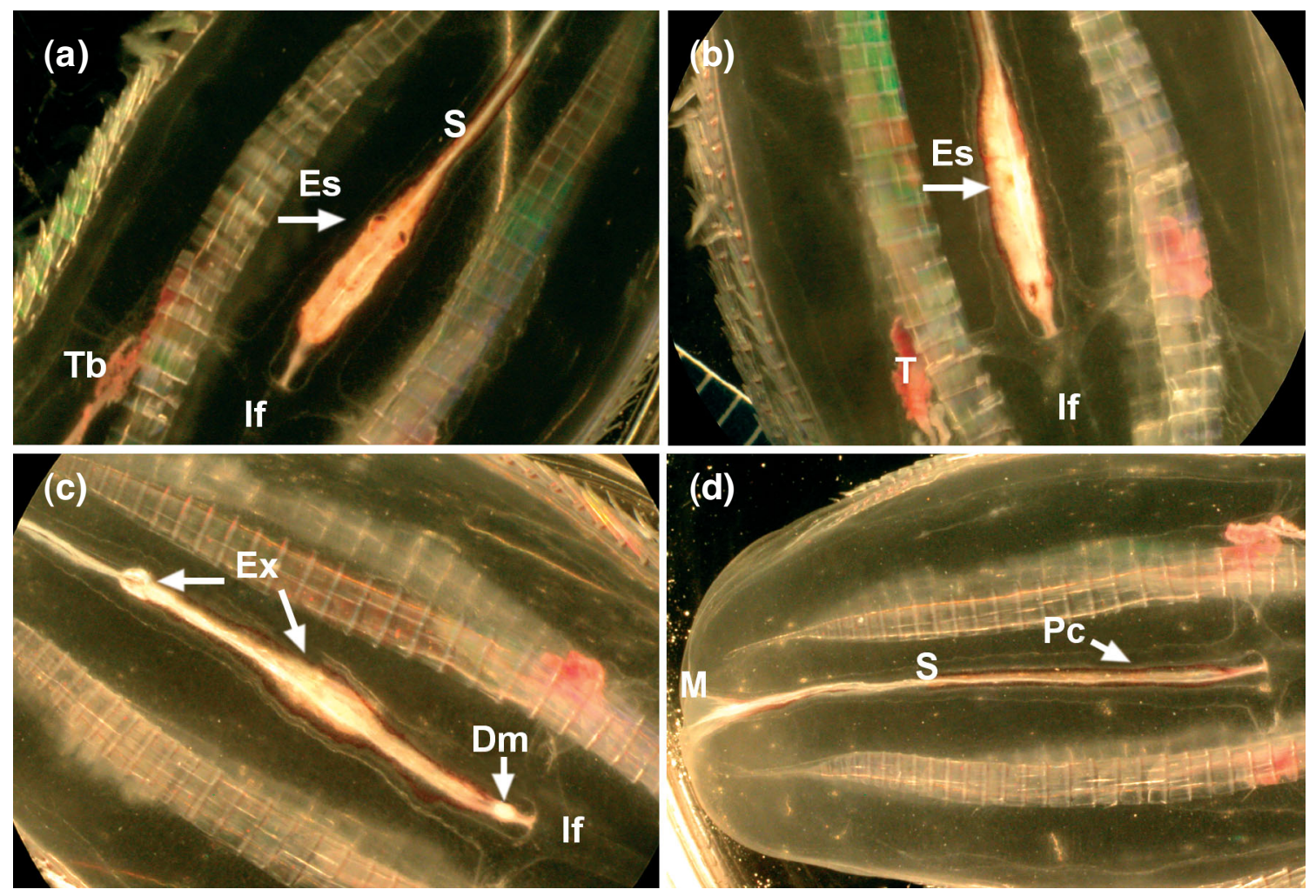

Fig. 7. Callianira antarctica digesting Euphausia superba furcilia Stage VI. Sequential images of prey in a ctenophore stomodeum illustrating different stages of digestion, based on the results of 18 winter experiments (temperature $=-1.3$ to $-1.8^{\circ} \mathrm{C}$ ). (a) Stage I: $(0 \mathrm{~h})$ newly ingested prey, usually accompanied by a small amount of tentacle mass in bottom of pharynx (not shown); (b) Stage II: ( 1 to $5 \mathrm{~h}$ ) prey losing distinguishable shape due to soft tissue digestion; (c) Stages III/IV: (2 to $9 \mathrm{~h}$ ) soft tissue completely separated from carapace, $(3$ to $18 \mathrm{~h})$ small amount $\left(\leq 1.0 \mathrm{~mm}^{2}\right)$ of digested tissue remaining in stomodeum; and (d) Stage V: (5 to $\left.21 \mathrm{~h}\right) \mathrm{most}$ or all soft tissue and/or exoskeletal pieces digested or egested. Es: E. superba; S: stomodeum; If: infundibulum; Tb: tentacle bulb; $\mathrm{T}$ : tentacle; Ex: exoskeleton; Dm: digested matter; M: mouth; PC: paragastric canal; ctenophore $=35 \mathrm{~mm}$ TL; E. superba $=8 \mathrm{~mm}$ TL

bison 1989). The presence/absence and net change in volume of lipid reserves in $C$. antarctica was observed before, during, and after winter digestion experiments (Fig. 8). Lipid was not present in stomodea at the beginning of $29 \%$ of the experiments (50\% using larval Euphausia superba as prey and $50 \%$ using Metridia gerlachii or Calanus propinquus). None of the ctenophores that ingested larval E. superba accumulated lipid after digestion, whereas lipids always accumulated from copepod digestion.

For ctenophores with lipid initially present (53\%), the lipid droplet always increased in volume, even when digesting krill larvae, although the amount varied with prey number and type. Digestion of Calanus propinquus resulted in the largest increase $(>100 \%)$ in lipid volume (Fig. 8). The percent increase in lipid volume from digesting Metridia gerlachii and euphausiid juveniles was consistently low, whereas the increase from larval Euphausia superba was variable.

\section{Gut contents}

The gut contents of Callianira antarctica during winter 2001 ( $\mathrm{n}=20)$, autumn $2002(\mathrm{n}=43)$, and winter 2002 ( $n=82$ ) were examined to investigate in situ feeding (Fig. 9). Ctenophores had a slightly greater feeding incidence (unrecognized digested matter + recognized prey) during autumn 2002 (58\%) than during winter 2001 (50\%) and 2002 (45\%). The percentage of empty guts was low $(<30 \%)$ during all seasons due to the frequent occurrence of lipid reserves in ctenophores that otherwise lacked evidence of prey. Lipids were observed more frequently during winter (2001: 30\%; 2002: $27 \%$ ), than autumn (21\%). Some ctenophores had multiple prey in their guts (winter 2001: 30\%; autumn 2002: $20 \%$; winter 2002: $8 \%$ ). Of these, some had multiple prey in different stages of digestion, indicating they had ingested prey at different times.

Euphausiid furcilia and small- to medium-sized (1 to $6 \mathrm{~mm}$ ) copepods were the main diet items during both autumn and winter (Fig. 10), with copepods 


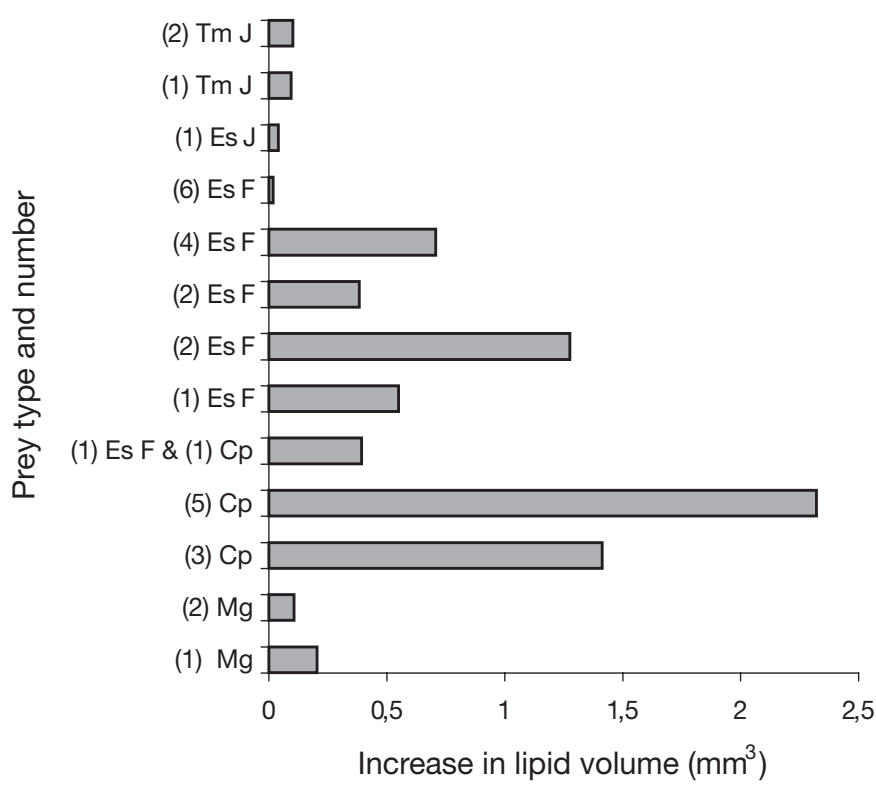

Fig. 8. Callianira antarctica. Measured increases in gut lipid volume after digestion of prey. The number (in parentheses) and type of prey digested are shown for each experiment. Es: Euphausia superba; Tm: Thysanoessa macrura; Cp: Calanus propinquus; Mg: Metridia gerlachii; J: juvenile; F: furcilia

being the dominant prey in autumn, and euphausiid larvae prevailing in winter. Copepod species that could be identified included Calanoides acutus, Metridia gerlachii, and Calanus propinquus. A single amphipod, Primno macropa, was also observed in the winter 2001 gut contents. Because a significant proportion of the gut material in all individuals was too digested to be identified, we could not determine reliable counts of total prey consumed per ctenophore nor could we estimate in situ feeding rates from gut contents.

\section{DISCUSSION}

\section{Chemical composition}

The elemental composition of Callianira antarctica was more variable in winter than in autumn, but not significantly different. Ctenophore body carbon is unevenly distributed among tentacles, the gut wall, and comb rows (Reeve et al. 1989); therefore, some of the variability in carbon may be attributed to loss of tentacles during net collections. Because geometric mean carbon and nitrogen values (Table 1) for both seasons were similar, averages of the pooled data are used in the discussion below.

Callianira antarctica has a high water content and low organic mass, which is characteristic of all gelati- nous zooplankton and of ctenophores in particular (Percy \& Fife 1981, Hoeger 1983, Clarke et al. 1992). The mean DW $(4.2 \% \mathrm{WW})$ is within the range (1 to $7 \%$ ) reported for other ctenophores (Kremer 1977, Hoeger 1983, Martinussen \& Båmstedt 1999), and closely resembles values given for other polar cydippids, such as Pleurobrachia sp. (4.4\%) from the Antarctic (Clarke et al. 1992), and P. pileus (4.0\%) and Mertensia ovum (4.5 to $4.9 \%$ ) from the Arctic (Hoeger 1983, Percy 1988). Because ctenophores are considered to be in isotonic equilibrium with their surrounding water, regional differences in salinity may impact comparisons of dry weight (Shiganova et al. 2001).

Carbon (8.41\% DW) and nitrogen (1.83\% DW) levels in Callianira antarctica were also similar to or higher than values for other ctenophores from polar regions, and higher than temperate and tropical species. For example, C. antarctica elemental values were similar to those for an Antarctic Beroe sp. (9.51 and 2.22\% DW; Clarke et al. 1992) and Mertensiidae species (11.2 and $2.4 \%$; Ikeda \& Bruce 1986), but 2-fold higher than values for an Antarctic Pleurobrachia sp. (4.11 and $0.74 \% \mathrm{DW}$; Clarke et al. 1992) and for P. pileus (C:3.4\%) from the Arctic (Hoeger 1983). C.antarctica elemental levels were also more than 4 times higher than those in epipelagic ctenophores from temperate and tropical regions (reviewed in Youngbluth et al. 1988). Thus, polar ctenophores tend to have elevated organic carbon levels relative to levels in species from lower latitudes, as previously noted by Ikeda (1974).

\section{Metabolic rates}

Metabolism, excretion, and carbon content for 12 other species of ctenophores inhabiting polar, temperate, and tropical regions are presented in Table 5 for comparison with Callianira antarctica. As noted in the previous section, the high water content of ctenophores (>95\%, Bailey et al. 1994) results in low, yet highly variable amounts of organic matter or metabolizing tissue, making interspecific comparisons a perilous road to follow. For the 13 species in Table 5, organic carbon content varies between 0.6 and $11.2 \%$ of DW, which has a profound effect on the DW-specific metabolism. Expressed in terms of dry weight, and with all species at normal ambient environmental temperature $\left(0\right.$ to $\left.25^{\circ} \mathrm{C}\right), \mathrm{C}$. antarctica's metabolism at $0.5^{\circ} \mathrm{C}$ ranks second out of 13 , falling just under a temperate species (Beroe cucumis, $15^{\circ} \mathrm{C}$ ) and comparable with a tropical species (Beroe ovata, $25^{\circ} \mathrm{C}$ ). Expressed as carbon and at ambient temperature, C. antarctica's metabolism ranks ninth, clustering with the rest of the polar species. If the inter-regional comparisons are taken one step further, by correcting all measurements of oxygen consumption to a common 


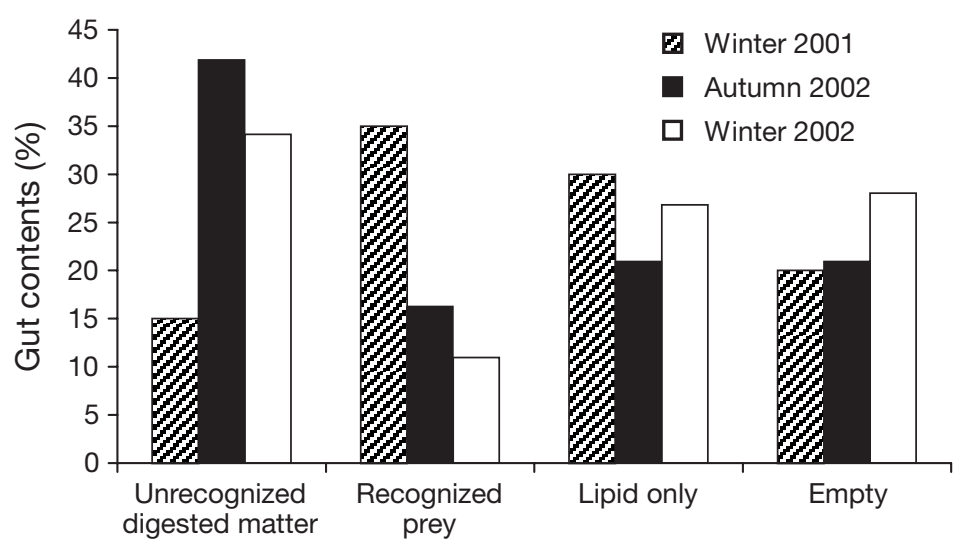

Fig. 9. Callianira antarctica. Gut contents of individuals collected during 3 seasons: winter $2001(\mathrm{n}=20)$, autumn $2002(\mathrm{n}=43)$, winter $2002(\mathrm{n}=82)$

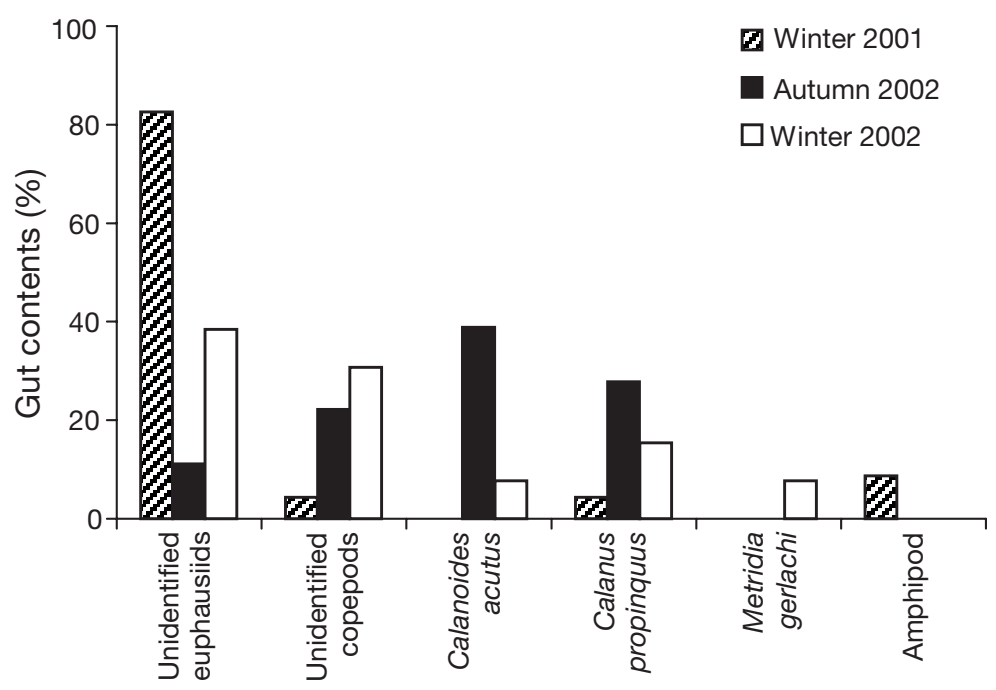

Fig. 10. Callianira antarctica. Prey type making up the 'recognizable prey' portion of gut contents from Fig. 9 during 3 seasons. Prey number: winter $2001(\mathrm{n}=23)$, autumn $2002(\mathrm{n}=18)$, winter $2002(\mathrm{n}=13)$

temperature of $0^{\circ} \mathrm{C}$ using a $Q_{10}$ of 2.0 (Hochachka \& Somero 2002), C. antarctica's carbon-specific metabolism $\left(2.641 \mathrm{\mu l} \mathrm{O}_{2} \mathrm{mg}^{-1} \mathrm{C} \mathrm{h}^{-1}\right)$ is the highest rate followed by the temperate predator Mnemiopsis leidyi $\left(2.059 \mathrm{\mu l} \mathrm{O}_{2} \mathrm{mg}^{-1} \mathrm{C} \mathrm{h}^{-1}\right)$. Like the other Antarctic mertensiid ctenophore shown in Table 5, C. antarctica's high carbon content and oxygen consumption rate suggest a very active predatory species with a cold adapted metabolism. The sluggish and very delicate mesopelagic species, Bathocyroe fosteri, provides a counterpoint to the more active species presented in Table 5, ranking at the bottom of the list for all rates.

Carbon-specific nitrogen excretion also shows a trend with temperature, in that polar and mesopelagic species have rates that are an order of magnitude lower than those in temperate and tropical species
(Table 5). Moreover, when excretion rates are extrapolated to $0^{\circ} \mathrm{C}$ there is no evidence of a cold adapted response, i.e. polar and tropical species having similar excretion rates; instead, the tropical species are actually higher (Table 5). These interesting differences in metabolism between high and low latitude ctenophores warrant further investigation.

Interestingly, the $\mathrm{O}: \mathrm{N}$ ratios observed in Callianira antarctica and the other polar species (mean 24) were about twice as high as those from the tropical regions (mean 13), suggesting a greater dependence on lipid in the polar species. Within C. antarctica, individual $\mathrm{O}: \mathrm{N}$ was highly variable (Table 2 ), suggesting a protein-based metabolism immediately after prey capture and a lipid-based metabolism post-digestion, depending on the type of prey ingested.

The relation of metabolism to weight in Callianira antarctica was typical of that reported for ctenophores in that $b$, the exponent in the equation $y=a x^{b}$, was close to 1.0 (0.92; Fig. 3) where $y$ is metabolic rate, $x$ is weight, and $a$ is a constant for the species. A $b$ value of 0.92 indicates that weight-specific metabolism declines only slightly with increasing weight. $b$ values for metabolism vs. weight are reported for 8 of the species in Table 5. The only species to have an exponent less than 0.9 is Bolinopsis vitrea, a tropical cydippid (Kremer et al. 1986a). Ctenophores as a group thus seem to have a consistently higher exponent than most taxa, whose $b$ values fall at approximately 0.75 (Prosser 1973). In contrast to oxygen consumption vs. mass, weight-specific excretion in C.antarctica showed a strong decline with increasing weight $(b=0.49)$, indicating either a lower hunting success in large individuals or a greater dependence on stored lipid, or both.

\section{Maintenance carbon rations and body turnover}

Smaller ( $\leq 30 \mathrm{~mm})$ Callianira antarctica required a higher daily carbon intake (1.17 to $8.91 \%$ body C) to support metabolic processes than larger ctenophores (>30 mm; 0.44 to $3.62 \%$ body C) during winter, owing to higher weight-specific respiration rates combined with a lower carbon content per unit weight. Our winter maintenance rations are much lower than the daily rations estimated from autumn ingestion experiments, suggesting that autumn feeding could have supported ctenophore growth, assuming that metabolic demand 


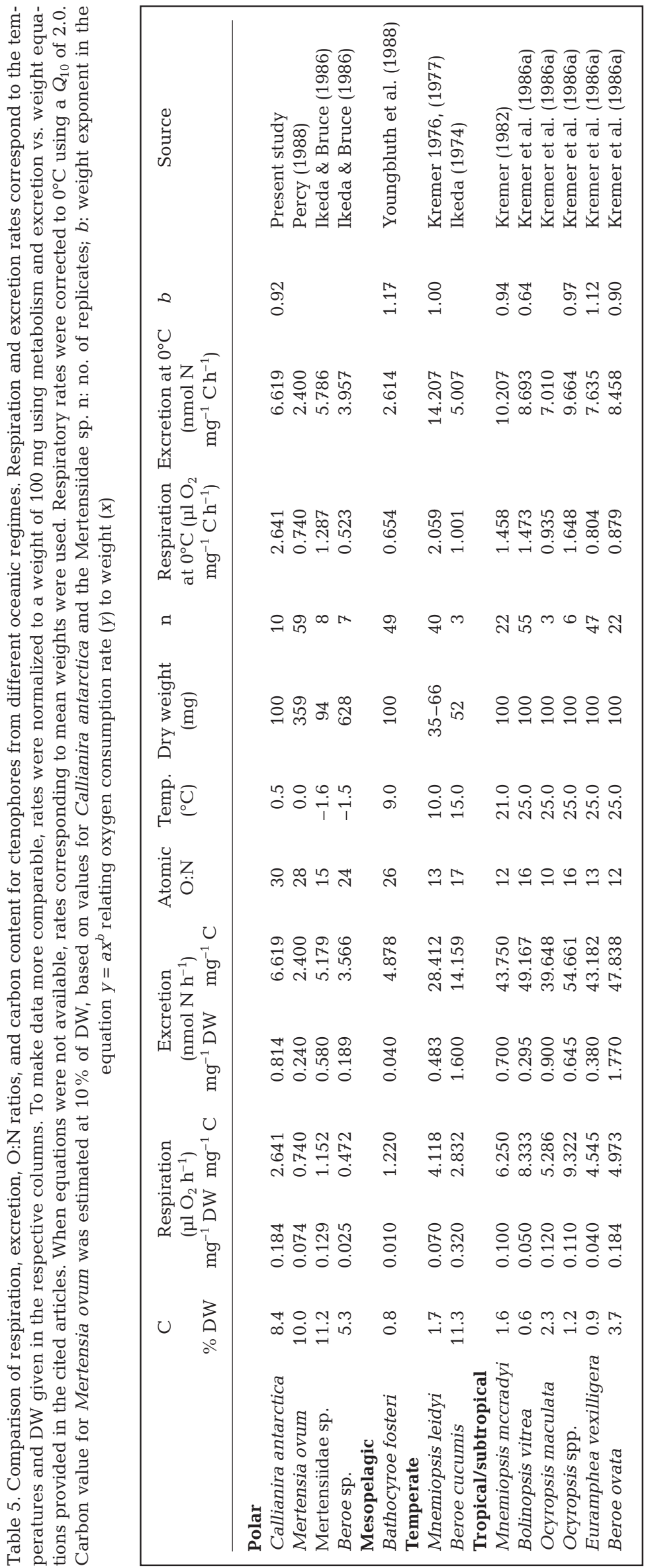

was similar. Even though winter feeding rates could not be estimated from gut contents, it is instructive to examine whether C. antarctica could have obtained sufficient food to support their metabolic requirements. If we assume a conservative assimilation efficiency of $70 \%$ (Reeve et al. 1978), the daily carbon requirement for smaller $C$. antarctica during winter would be satisfied with the ingestion of 1 larval (F6) Euphausia superba, 1 adult Calanus propinquus, or 2 Metridia gerlachii. Larger ctenophores would need to ingest up to 6 larval (F6) E. superba, 16 M. gerlachii, 3 C. propinquus or 1 juvenile E. superba or Thysanoessa macrura each day. If we consider average digestion times (e.g. 10.0 and $16.5 \mathrm{~h}$ for prey items under 1.0 and $2.0 \mathrm{mg} \mathrm{C}$, respectively) and allow for multiple meals, gut contents from this study suggest that $C$. antarctica could meet, and often exceed, the maintenance daily carbon requirement, even during winter.

\section{Feeding ecology: experimental}

Callianira antarctica clearance rates are comparable to the lower end of rates reported for tropical and temperate ctenophores (range: 0.3 to $531 \mathrm{lnd}^{-1} \mathrm{~d}^{-1}$, water temperature range: 16 to $30^{\circ} \mathrm{C}_{i}$ Larson 1987b, Stoecker et al. 1987, Monteleone \& Duguay 1988, Kremer \& Reeve 1989, Buecher \& Gasser 1998, Purcell et al. 2001). The temperature difference between our experiments and those reported in the literature from warmer climates is a major factor contributing to the lower clearance rates. A 4 to 8 -fold increase in feeding rates would be conservatively expected between polar and tropical species based on temperature alone. Although container volume has been shown to influence feeding rates of ctenophores (Monteleone \& Duguay 1988, Gibbons \& Painting 1992, Buecher \& Gasser 1998), there were no obvious differences in our rates between the 8 and 251 containers for the larger C. antarctica (Table 3). Toonen \& Chia (1993) suggested that an animal-to-container volume ratio below 1:15000 influenced prey selection by the hydrozoan jellyfish Proboscidactyla flavicirrata. However, their ingestion rates decreased by only $\sim 15 \%$ in these containers and were rather a function of the 2 


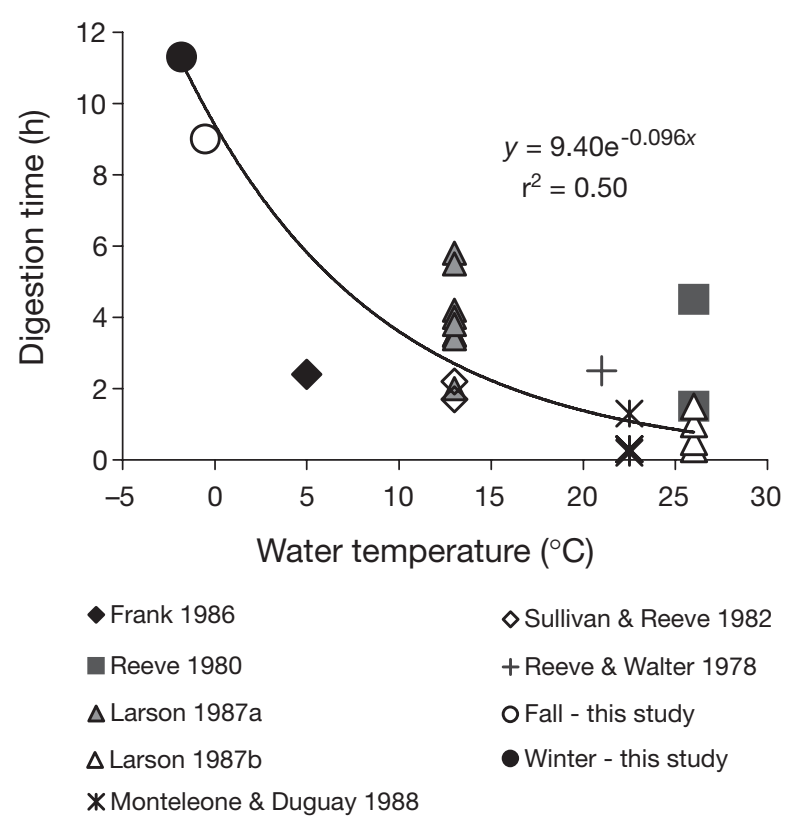

Fig. 11. Relationship between digestion time and incubation temperature for ctenophores from different regions. Data sources are shown in the figure legend, Callianira antarctica rates are designated by the open and closed circles

order of magnitude drop in prey concentrations. Given these results, our rates may be underestimated as well.

Our experimental prey concentrations were 2 orders of magnitude higher than mean in situ zooplankton

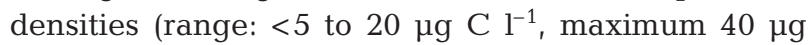
$\mathrm{C}^{-1}$ ) obtained using Bongo nets in the top $300 \mathrm{~m}$ during April/May 2001 (E. A. Pakhomov unpubl.). ROV observations, however, indicated that larval krill den-

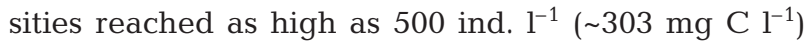
under sea ice (S. Gallager pers. comm.); thus, experimental prey concentrations were within the range of concentrations Callianira antarctica may have encountered in situ. Based on in vitro ingestion rates, daily rations for C. antarctica ranged from 6 to $136 \%$ of total body carbon. At the highest mean in situ zooplankton biomass $\left(\sim 40 \mu \mathrm{g} \mathrm{C}^{-1}\right)$ a minimum daily ration for the larger ctenophore, using the equation in Fig. 4, would be $17 \%$ of body carbon. By comparison, Reeve (1980) estimated daily rations for temperate ctenophores to be $>200 \%$ of body $\mathrm{C} \mathrm{d}^{-1}$ for food concentrations exceeding $1000 \mu \mathrm{g} \mathrm{C}^{-1}$. Since we know little about either ctenophore or prey densities in the Southern Ocean, predation impact assessments are beyond the scope of this study. Nevertheless, our preliminary in vitro ingestion rates point out that $C$. antarctica could have a high predation impact over a wide range of natural prey concentrations. Depending on ctenophore density, their predation impact could be particularly noticeable during winter, when secondary productivity is low.

\section{Digestion time}

Slow digestion may be the limiting factor in the amount of carbon Callianira antarctica can process. Autumn (9 h) and average winter (11.5 h) digestion times were substantially longer than values reported for temperate and tropical ctenophores (Fig. 11; range 0.2 to $5.8 \mathrm{~h}$, temperature $=5$ to $26^{\circ} \mathrm{C}$ ). Copepods in tropical waters $\left(25\right.$ to $27^{\circ} \mathrm{C}$ ) are typically digested in less than 3 h (Reeve 1980, Kremer et al. 1986b, Larson 1987a), whereas C. antarctica took 9 to $12 \mathrm{~h}$ to digest a single copepod. To our knowledge, there are no other digestion times for polar ctenophores available for comparison. Temperature alone explained $50 \%$ of the variation in digestion times of ctenophores from different latitudes that had ingested a variety of prey types, ranging from fish eggs to euphausiid larvae (Fig. 11). In addition, the larger size and greater carbon content of prey from higher latitudes will influence digestion rates, as our data suggest.

Variability in winter digestion times for Callianira antarctica was primarily due to differences in carbon content of prey, and, to a lesser extent, prey number, but was independent of ctenophore size. The lack of correlation between digestion time and ctenophore size, and a positive correlation with prey number has also been observed in other studies (Reeve 1980, Larson 1987a, Martinussen \& Båmstedt 1999).

\section{Lipid storage}

Callianira antarctica assimilation efficiencies appeared to be very high since they egested little, other than clear pieces of disarticulated exoskeleton. The major organic component of exoskeletons is chitin, which on average is $4.6 \%$ DW in copepods (Båmstedt 1986) and $4.0 \%$ DW in Euphausia superba (Raymont 1983); hence, carbon assimilation efficiencies could be $>90 \%$. Although relatively low assimilation efficiencies have been reported for other ctenophores (74\% for Mnemiopsis mccradyi and Pleurobrachia bachei; Reeve et al. 1978), Purcell (1983) found high carbon assimilation efficiencies (87 to $94 \%$ ) for siphonophores and suggested that environments with low food availability required efficient digestion of prey.

The accumulation of lipid droplets in the stomodeum of Callianira antarctica, however, indicates that some portion of prey carbon is not immediately assimilated. The Arctic ctenophore Mertensia ovum is known to store lipids after feeding on copepods, which Percy (1988) suggested was a survival strategy during times of low food availability. Our digestion rate experiments indicated that copepods were the primary source of lipid stores in C. antarctica, since the largest changes in 
lipid volumes occurred after digesting copepods, particularly Calanus propinquus. The lack of lipid accumulation after ingesting lipid-rich Thysanoessa macrura may have resulted from the long digestion times or the types of fatty acids associated with this prey.

$\mathrm{Ju}$ et al. (2004) analyzed lipids in Callianira antarctica body tissues (gut contents and lipids removed) as well as lipid biomarkers from potential prey from our study area. Their findings suggest that lipid content in ctenophores is higher in winter than in autumn, and that fatty acids specific to larval Euphausia superba and fatty alcohols from wax esters found in calanoid copepods are elevated in ctenophores in winter. Therefore, lipid reserves may be important to C. antarctica's overwintering survival.

\section{Feeding ecology: in situ}

Diver and ROV observations of ctenophore predatory behavior during day and night, and the presence of prey in the guts of ctenophores collected during late afternoon and evening net tows, suggest that Callianira antarctica forages for food continuously over a $24 \mathrm{~h}$ period. Feeding success was moderate, regardless of season, as 40 to $50 \%$ of ctenophore guts during autumn and both winters did not contain any digested material. The large percentage of guts lacking prey could be an artifact of net collection (ctenophore regurgitation) or our efforts to reduce net feeding bias by not including freshly ingested prey in our estimates. Some of the excluded ctenophores had up to 11 larval krill in their guts. The similarity in feeding incidence between autumn and winter, despite a large seasonal variability in prey abundance, suggests that other factors, such as prey patchiness, may significantly influence feeding. High frequencies of empty guts were also reported for Mertensia ovum (52 to $70 \%$ ) during early spring and summer from the Arctic (Siferd \& Conover 1992), where prey densities are also highly seasonal.

Recognizable prey in gut contents indicated that Callianira antarctica were primarily feeding on larval euphausiids during winter 2001, on copepods during autumn 2002, and on both larval euphausiids and copepods during winter 2002. Tentaculate ctenophores are opportunistic feeders and, as a result, their gut contents should reflect encountered in situ prey concentrations and composition (Frank 1986, Siferd \& Conover 1992). Diver and ROV observations under sea ice and results from net tows (Daly 2004, Ashjian et al. 2004) over 3 seasons correspond well with ctenophore gut contents: larval Euphausia superba concentrations in the study area were highest during winter 2001, lowest during autumn 2002, and variable in winter 2002. Ctenophores may compensate for the seasonal decrease in prey abundance and increase in food patchiness during winter by exploiting larval krill aggregations under sea ice. Hence, high densities of larval krill under sea ice may provide a significant food source for overwintering $C$. antarctica and, conversely, C. antarctica may significantly affect krill mortality.

Acknowledgements. We thank the Captains and crews of the RV 'Polarstern', RV 'Lawrence M. Gould', and the RVIB 'Nathaniel B. Palmer' and Raytheon Polar Services personnel for their outstanding support at sea. We are grateful to A. Atkinson, E. Yam, J. Zimmerman, T. Bailey, and J. Donnelly for their assistance with experimental work and data analyses, and to G. Matsumoto for his advice and taxonomic expertise. We also thank K. Fanning and S. Bell for excretion analyses and P. Wiebe for use of his Reeve net. We extend our warmest appreciation to C. McDonald, J. Bellucci, M. Parker, and $\mathrm{S}$. Alesandrini for their assistance with diver observations and collections. Comments and suggestions by P. Kremer and 2 anonymous reviewers substantially improved the manuscript. This research was supported by NSF grants OPP9910610 and OPP-0196489 (K.D.), an AAUS scholarship (K.S.), and OPP-9910100 (J.T.). Funding and facilities were provided to E.P. by the University of Fort Hare (South Africa), the Alfred-Wegener-Institute for Polar and Marine Research (Germany), and the Alexander von Humboldt Foundation (Germany). This publication represents GLOBEC contribution No. 265.

\section{LITERATURE CITED}

Ashjian CJ, Rosenwaks GA, Wiebe PH, Davis CS, Gallager SM, Copley NJ, Lawson GL, Alatalo P (2004) Distribution of zooplankton on the continental shelf off Marguerite Bay, Antarctic Peninsula, during austral fall and winter, 2001. Deep-Sea Res II 51:2073-2098

Bailey TG, Youngbluth MJ, Owen GP (1994) Chemical composition and oxygen consumption rates of the ctenophore Bolinopsis infundibulum from the Gulf of Maine. J Plankton Res 16:673-689

Båmstedt U (1986) Chemical composition and energy content. In: Corner EDS, O'Hara SCM (eds) The biological chemistry of marine copepods. Clarendon Press, Oxford, p 1-58

Buecher E, Gasser B (1998) Estimation of predatory impact of Pleurobrachia rhodopis (cydippid ctenophore) in the northwest Mediterranean Sea: in situ observations and laboratory experiments. J Plankton Res 20:631-651

Clarke A, Holmes LJ, Gore DJ (1992) Proximate and elemental composition of gelatinous zooplankton from the Southern Ocean. J Exp Mar Biol Ecol 155:55-68

Daly KL (2004) Overwintering growth and development of larval Euphausia superba: an interannual comparison under varying environmental conditions west of the Antarctic Peninsula. Deep-Sea Res II 51:2139-2168

Daly KL, Macaulay MC (1991) The influence of physical and biological mesoscale dynamics on the seasonal distribution and behavior of Euphausia superba in the Antarctic marginal ice zone. Mar Ecol Prog Ser 79:37-66

Frank KT (1986) Ecological significance of the ctenophore Pleurobrachia pileus off southwestern Nova Scotia. Can JFish Aquat Sci 43:211-222

Frost BW (1972) Effects of size and concentration of food particles on the feeding behaviour of the marine planktonic copepod Calanus pacificus. Limnol Oceanogr 17:805-815 
Gibbons MJ, Painting SJ (1992) The effects and implications of container volume on clearance rates of the ambush entangling predator Pleurobrachia pileus (Ctenophora: Tentaculata). J Exp Mar Biol Ecol 63:199-208

Gnaiger E (1983) Calculation of energetic and biochemical equivalents of respiratory oxygen consumption. In: Gnaiger E, Forstner H (eds) Polarographic oxygen sensors. Springer-Verlag, Berlin, p 337-345

Gordon LI, Jennings JC Jr, Ross AA, Krest JM (1993) A suggested protocol for continuous flow automated analysis of seawater nutrients. In: World Ocean Circulation Experiment (WOCE) operations manual. WHP office report 90-1, WOCE report 77 No. 68/91:1-52

Greene CH (1985) Planktivore functional groups and patterns of prey selection of pelagic communities. J Plankton Res 7 : 35-40

Greene CH, Landry MR, Monger BC (1986) Foraging behavior and prey selection by the ambush entangling predator Pleurobrachia bachei. Ecology 67:1493-1501

Hamner WM, Hamner PP (2000) Behavior of Antarctic krill (Euphausia superba): schooling, foraging, and antipredatory behavior. Can J Fish Aquat Sci 57:192-202

Hamner WM, Hamner PP, Obst BS (1989) Field observations on the ontogeny of schooling of Euphausia superba furciliae and its relationship to ice in Antarctic waters. Limnol Oceanogr 34:451-456

Harbison GR, Madin LP, Swanberg NR (1978) On the natural history and distribution of oceanic ctenophores. Deep-Sea Res 25:233-256

Hochachka PW, Somero GN (2002) Biochemical adaptation: mechanism and process in physiological evolution. Oxford University Press, Oxford

Hoeger U (1983) Biochemical composition of ctenophores. JExp Mar Biol Ecol 72:252-261

Hopkins TL (1985) Food web of an Antarctic midwater ecosystem. Mar Biol 89:197-212

Hopkins TL, Lancraft TM, Torres JJ, Donnelly J (1993) Community structure and trophic ecology of zooplankton in the Scotia Sea marginal ice zone in winter (1988). Deep-Sea Res 140:81-105

Huntley ME, Sykes PF, Marin V (1989) Biometry and trophodynamics of Salpa thompsoni Foxton (Tunicata: Thaliacea) near the Antarctic Peninsula in austral summer, 1983-1984. Polar Biol 10:59-70

Ikeda T (1974) Nutritional ecology of marine zooplankton. Mem Fac Fish Hokkaido Univ 22:1-97

Ikeda T, Bruce B (1986) Metabolic activity and elemental composition of krill and other zooplankton from Prydz Bay, Antarctica, during early summer (November-December). Mar Biol 92:545-555

Ikeda T, Torres JJ, Hernandez-Leon S, Geiger SP (2000) Metabolism. In: Harris RP, Wiebe PH, Lenz J, Skoldal HR, Huntley M (eds) ICES zooplankton methodology manual. Academic Press, London and San Diego, p 455-532

Ju SJ, Scolardi KM, Daly KL, Harvey HR (2004) Understanding the trophic role of the Antarctic ctenophore, Callianira antarctica, using lipid biomarkers. Polar Biol 27(12): 782-792

Kaufmann RS, Fisher ER, Gill W, King AL, Laubacher M, Sullivan B (2003) Seasonal patterns in macrozooplankton/ micronekton distribution, abundance, biomass and species diversity within Port Foster, Deception Island, Antarctica. Deep-Sea Res II 50:1753-1763

Klinck JM, Hofmann EE, Beardsley RC, Salihohlu B, Howard S (2004) Water-mass properties and circulation on the west Antarctic Peninsula continental shelf in austral fall and winter 2001. Deep-Sea Res II 51:1925-1946
Kremer P (1976) Excretion and body composition of the ctenophore Mnemiopsis leidyi (A. Agassiz): comparisons and consequences. In: Proc 10th Eur Mar Biol Symp, Ostend, Vol 2: Population dynamics. Universal Press, Wetteren, p351-362

Kremer P (1977) Respiration and excretion by the ctenophore Mnemiopsis leidyi. Mar Biol 44:43-50

Kremer P (1982) Effect of food availability on the metabolism of the ctenophore Mnemiopsis mccradyi. Mar Biol 71: 149-156

Kremer P, Reeve MR (1989) Growth dynamics of a ctenophore (Mnemiopsis) in relation to variable food supply. II. Carbon budgets and growth model. J Plankton Res 11: 553-574

Kremer P, Canino MF, Gilmer RW (1986a) Metabolism of epipelagic tropical ctenophores. Mar Biol 90:403-412

Kremer P, Reeve MR, Syms MA (1986b). The nutritional ecology of the ctenophore Bolinopsis vitrea: comparisons with Mnemiopsis mccradyi from the same region. J Plankton Res 8:1197-1208

Lancraft TM, Torres JJ, Hopkins TL (1989) Micronekton and macrozooplankton in the open waters near Antarctic ice edge zones (AMERIEZ 1983 and 1986). Polar Biol 9: $225-233$

Lancraft TM, Hopkins TL, Torres JJ, Donnelly J (1991) Oceanic micronektonic/macrozoo-planktonic community structure and feeding in ice covered Antarctic waters during the winter (AMERIEZ 1988). Polar Biol 11:157-167

Larson RJ (1987a) In situ feeding rates of the ctenophore Mnemiopsis mccradyi. Estuaries 10:87-91

Larson RJ (1987b) Trophic ecology of planktonic gelatinous predators in Saanich Inlet, British Columbia: diets and prey selection. J Plankton Res 9:811-820

Larson RJ, Harbison GR (1989) Source and fate of lipids in polar gelatinous zooplankton. Arctic 42:339-346

Laws EA, Archie JW (1981) Appropriate use of regression analysis in marine biology. Mar Biol 65:13-16

Martinussen MB, Båmstedt U (1999) Nutritional ecology of gelatinous planktonic predators. Digestion rate in relation to type and amount of prey. J Exp Mar Biol Ecol 232:61-84

Mills CE (1995) Medusae, siphonophores, and ctenophores as planktivorous predators in changing global ecosystems. ICES J Mar Sci 52:575-581

Monteleone DM, Duguay LE (1988) Laboratory studies of predation by the ctenophore Mnemiopsis leidyi on the early stages in the life history of the bay anchovy, Anchoa mitchilli. J Plankton Res 10:359-372

Pages F (1997) The gelatinous zooplankton in the pelagic system of the Southern Ocean: a review. Ann Inst Oceanogr 73(2):139-158

Pages F, Kurbjeweit F (1994) Vertical distribution and abundance of mesopelagic medusae and siphonophores from the Weddell Sea, Antarctica. Polar Biol 14:243-251

Pages F, White MG, Rodhouse PG (1996) Abundance of gelatinous carnivores in the nekton community of the Antarctic Polar Frontal Zone in summer 1994. Mar Ecol Prog Ser 141:139-147

Pakhomov EA (1989) Macroplankton distribution in the central part of the Indian sector of Antarctica during summer of 1984-1986. The Antarctic, Nauka Press, Moscow, 28: 145-158 (in Russian with English abstract)

Percy JA (1988) Influence of season, size and temperature on the metabolism of the arctic cydippid ctenophore, Mertensia ovum (Fabricius). Sarsia 73:61-70

Percy JA, Fife FJ (1981) The biochemical composition and energy content of arctic marine zooplankton. Arctic 34: $307-313$ 
Piatkowski U, Rodhouse PG, White MG, Bone DG, Symon C (1994) Nekton community of the Scotia Sea as sampled by the RMT 25 during austral summer. Mar Ecol Prog Ser 112:13-28

Prosser CL (1973) Comparative animal physiology. Saunders, Philadelphia

Purcell JE (1983) Digestion rates and assimilation efficiencies of siphonophores fed zooplankton prey. Mar Biol 73:257-261

Purcell JE (1997) Pelagic cnidarians and ctenophores as predators: selective predation, feeding rates, and effects on prey populations. Ann Inst Oceanogr 73:125-137

Purcell JE, Shiganova TA, Decker MB, Houde ED (2001) The ctenophore Mnemiopsis in native and exotic habitats: U.S. estuaries versus the Black Sea basin. Hydrobiologia 451: 145-176

Raymont JEG (1983) Plankton and productivity in the oceans, Vol 2 Zooplankton. Pergamon Press, Oxford

Reeve MR (1980) Comparative experimental studies on the feeding of chaetognaths and ctenophores. J Plankton Res 2:381-393

Reeve MR, Walter MA (1976) A large-scale experiment on the growth and predation potential of ctenophore populations. In: Mackie G (ed) Coelenterate ecology and behaviour. Plenum Publishing Company, New York, p 187-199

Reeve MR, Walter MA (1978) Nutritional ecology of ctenophores - a review of recent research. Adv Mar Biol 15:249-287

Reeve MR, Walter MA, Ikeda T (1978) Laboratory studies of ingestion and food utilization in lobate and tentaculate ctenophores. Limnol Oceanogr 23:740-751

Reeve MR, Syms MA, Kremer P (1989) Growth dynamics of a ctenophore (Mnemiopsis) in relation to variable food supply. I. Carbon biomass, feeding, egg production, growth and assimilation efficiency. J Plankton Res 11:535-552

Shiganova TA, Bulgakova YV (2002) Effects of gelatinous plankton on Black Sea and Sea of Azov fish and their food resources. ICES J Mar Sci 57:641-648

Shiganova, TA, Bulgakova YV, Volovik SP, Mirzoyan ZA, Dudkin SI (2001) The new invader Beroe ovata Mayer 1912 and its effect on the ecosystem in the northeastern Black Sea. Hydrobiologia 451:187-197

Editorial responsibility: Michael Landry,

La Jolla, California, USA
Siferd TD, Conover RJ (1992) Natural history of ctenophores in the Resolute Passage area of the Canadian High Arctic with special reference to Mertensia ovum. Mar Ecol Prog Ser 86:133-144

Stoecker DK, Verity PG, Michaels AE, Davis LH (1987) Feeding by larval and post-larval ctenophores on microzooplankton. J Plankton Res 9:667-683

Sullivan BK, Reeve MR (1982) Comparison of estimates of the predatory impact of ctenophores by two independent techniques. Mar Biol 68(1):61-65

Suthers IM, Frank KT (1990) Zooplankton biomass gradient off south-western Nova Scotia: Nearshore ctenophore predation or hydrographic separation? J Plankton Res 12(4): 831-850

Swanberg N, Båmstedt U (1991a) The role of prey stratification in the predation pressure by the cydippid ctenophore Mertensia ovum in the Barents Sea. Hydrobiologia 216/217:343-349

Swanberg N, Båmstedt U (1991b) Ctenophora in the Arctic: the abundance, distribution and predatory impact of the cydippid ctenophore Mertensia ovum (Fabricius) in the Barents Sea. Polar Res 10:507-524

Toonen RJ, Chia FS (1993) Limitations of laboratory assessments of coelenterate predation: container effects on the prey selection of the Limnomeduzasa, Proboscidactyla flavicirrata (Brandt). J Exp Mar Biol Ecol 167:215-235

Voronina NM (1998) Comparative abundance and distribution of major filter-feeders in the Antarctic pelagic zone. J Mar Syst 17:375-390

Voronina NM, Kosobokova KN, Pakhomov EA (1994) Composition and biomass of summer metazoan plankton in the 0-200 m layer of the Atlantic sector of the Antarctic. Polar Biol 14:91-95

Withers PC (1992) Comparative animal physiology. Saunders, Orlando

Youngbluth MJ, Kremer P, Bailey TG, Jacoby CA (1988) Chemical composition, metabolic rates and feeding behavior of the midwater ctenophore Bathocyroe fosteri. Mar Biol 98:87-94

Zar JH (1990) Biostatistical analysis. Prentice Hall, New Jersey

Submitted: January 12, 2005; Accepted: October 24, 2005

Proofs received from author(s): June 16, 2006 